\title{
POPULATION BIOLOGY OF THE BARBEL DRUM Ctenosciaena gracilicirrhus (METZELAAR, 1919) (PERCIFORMES: SCIAENIDAE) IN CARAGUATATUBA BAY, SOUTHEASTERN BRAZIL
}

\author{
Maíra Pombo ${ }^{1, *}$, Márcia Regina Denadai ${ }^{2}$, Flávia Borges Santos ${ }^{3}$, Eduardo Bessa ${ }^{4}$, \\ Cristiane Moraes ${ }^{l}$ and Alexander Turra ${ }^{l}$ \\ ${ }^{1}$ Instituto Oceanográfico da Universidade de São Paulo \\ (Praça do Oceanográfico, 191, 05508-120 São Paulo, SP, Brasil) \\ ${ }^{2}$ Instituto Costa Brasilis - Desenvolvimento Sócio-Ambiental \\ (Rua Emiliano Cardoso de Mello, 46, 05360-000 São Paulo, SP, Brasil) \\ ${ }^{3}$ Universidade Estadual do Sudoeste da Bahia \\ (Estrada do Bem Querer, km 04, 45083-900, Vitória da Conquista, BA, Brasil) \\ ${ }^{4}$ Universidade do Estado de Mato Grosso \\ (Av. dos Ingás, 3001, 78550-000 Sinop, MT, Brasil) \\ *Corresponding author: mpombo@usp.br
}

\section{A B S T R A C T}

This study evaluated the population biology of Ctenosciaena gracilicirrhus (Perciformes: Sciaenidae) in a shallow non-estuarine coastal area of southeastern Brazil. Monthly samples were taken from October 2003 through October 2004, in two distinct areas at depths from 1 to $4 \mathrm{~m}$. $C$. gracilicirrhus was generally among the most abundant fish species during the period. Its density was significantly higher in a single sampling month, May 2004, in the South area, which may be explained by its migratory behavior together with its preference for deeper areas. Such behavior may lead to bias in community estimates that use few or only seasonal samples. C. gracilicirrhus individuals ranged from 4.0 to $10.2 \mathrm{~cm}$ long, with a main mode from 7.5 to $9.0 \mathrm{~cm}$ and a significant decrease in mean size from June onward. The estimation of body growth parameters was compromised by this population feature. Similarly, the prey spectrum was difficult to determine because of the deteriorated condition of the stomach contents, although crustaceans were clearly the most important items ingested. Amphipoda was the only subgroup that could be identified more precisely, mainly by the construction of their tubes.

\section{RESUMO}

Este estudo levantou dados sobre a biologia populacional de Ctenosciaena gracilicirrhus (Perciformes: Sciaenidae) em uma região costeira rasa, não-estuarina, do sudeste do Brasil. Amostras mensais foram realizadas de outubro de 2003 a outubro de 2004, em duas áreas distintas e similares, com variação batimétrica de 1-4 m. A espécie esteve, em geral, entre os peixes mais abundantes. No entanto, sua densidade foi significativamente maior em um único mês e área, maio de 2004 na área sul. $\mathrm{O}$ fato pode ser explicado pelo seu comportamento migratório e uma preferência por regiões mais profundas. Esse comportamento pode levar a vieses em estudos de comunidade ictíica que usam poucas amostras, ou apenas amostras sazonais. Indivíduos de $C$. gracilicirrhus de 4,0 a $10,2 \mathrm{~cm}$ de comprimento total foram amostrados, apresentando uma moda principal de 7,5-9,0 cm e uma redução significativa do tamanho de junho de 2004 em diante. As estimativas de parâmetros de crescimento foram comprometidas pelas características peculiares da população no local. De forma semelhante, a identificação das presas foi comprometida devido ao elevado nível de deterioração do conteúdo estomacal. Foi possível concluir, entretanto, que os crustáceos foram nitidamente os itens mais importantes ingeridos. Amphipoda mostrou ser o único subgrupo identificável, principalmente devido à construção de tubos.

Descriptors: Abundance, Total length, Temporal variation, Shallow coastal area.

Descritores: Abundância, Comprimento total, Variação temporal, Área costeira rasa. 


\section{INTRODUCTION}

Coastal areas are under increasing pressure. As transitional environments they are constituted of a mosaic of ecosystems, which together support numerous species. Caraguatatuba Bay is an area of shallow, non-estuarine waters that are subject to various environmental impacts (sewage disposal, proximity to urban centers), and is also one of the most important artisanal-fishery grounds on the northern coast of the state of São Paulo (SÃO PAULO, 2005). Although this bay is highly disturbed and is adjacent to one of the most important urban centers in the country, there is still considerable lack of knowledge about its fish community.

Shallow coastal areas may serve as residence for both juvenile and adult fish, and are also an important transitional zone through which early juveniles move from estuaries to deeper waters as they mature to adulthood (GILLANDERS et al., 2003). In spite of this importance, fish in surf zones and other shallow coastal areas usually have not been specifically studied. Sciaenids are important components of the ichthyofauna in temperate to tropical estuaries and coastal waters (SASAKI, 1989). Most of the more than 270 species of this family lack commercial value, although they tend to appear in large numbers in trawl catches.

Most species of fish in Caraguatatuba Bay have minimal commercial value and are massively discarded as bycatch, which is the case of Ctenosciaena gracilicirrhus. Commonly named the barbel drum, or, in Caraguatatuba Bay, Betara-donorte, C. gracilicirrhus is a member of the family Sciaenidae (drums or croakers) and occurs along the west coast of the Atlantic from Nicaragua to southern Brazil $\left(13^{\circ} \mathrm{N}\right.$ to $34^{\circ} \mathrm{S}$ and $77^{\circ}$ to $\left.38^{\circ} \mathrm{W}\right)$. The barbel drum is demersal, tropical to subtropical, inhabits coastal areas at depths of 10 to $130 \mathrm{~m}$, usually at 10 to $80 \mathrm{~m}$, and feeds mainly on shrimp (CHAO, 1978; CERVIGÓN MARCOS, 1993).

The barbel drum was first recorded for the Brazilian coast by Menezes (1971). Its ecology has still been little studied, even though it is often highly abundant in nearshore areas (CUNNINGHAM, 1989; ARAÚJO et al., 2006; ROCHA et al., 2010). With a view to contributing to knowledge of the species and specifically to assessing the role of Caraguatatuba Bay in the population biology of $C$. gracilicirrhus, the present study evaluated its spatiotemporal distribution in relation to abundance and size. A broader assessment of the population biology, including estimates of body growth parameters and diet, was also undertaken. However, these estimates were unsatisfactory because of the species' peculiar distribution pattern and highly deteriorated stomach contents.
The results for spatial and temporal distribution, though, suggest that the number of individuals in the area fluctuates widely and can be determined accurately only by thorough sampling.

\section{Material and Methods}

\section{Study Area}

Caraguatatuba Bay $\left(23^{\circ} 37^{\prime} \mathrm{S}\right.$ to $23^{\circ} 44^{\prime} \mathrm{S}$ and $45^{\circ} 24^{\prime} \mathrm{W}$ to $45^{\circ} 26^{\prime} \mathrm{W}$ ) is about $16 \mathrm{~km}$ long and is bounded by several sandy beaches (Enseada, Flecheiras, Porto Novo, Romance, Palmeiras, PanBrasil, Indaiá, Centro and Camaroeiros). Two areas of the bay, each $2 \times 0.8 \mathrm{~km}$, homogeneous but distinct from each other, were selected for this study (Fig. 1). The first, or South, area extends from Porto Novo to Palmeiras beaches; it has a gentler slope, is more exposed to wave activity, and is more influenced by the Juqueriquerê River which forms a small estuary. The second, or North, area extends from Indaiá to Centro beaches, has a steeper slope, is relatively sheltered from wave action, and is influenced only by small rivers (Lagoa and Santo Antônio).

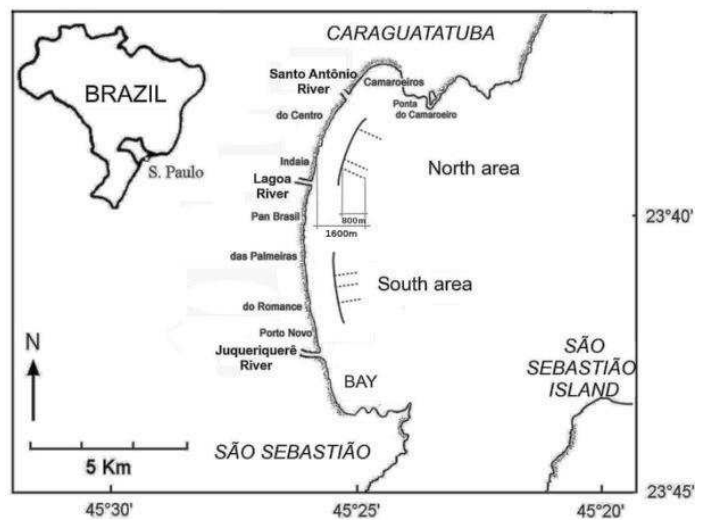

Fig. 1. Caraguatatuba Bay and otter-trawl sampling schemes from a monthly sample (dashed lines), in both study areas, North and South (solid lines).

\section{Sampling Procedures}

Monthly samples were taken from October 2003 through October 2004, under license from the federal environmental agency responsible (IBAMADIREN No. 08/2001). Three sampling stations were randomly selected in each area, South and North, among 200 possibilities, i.e., the beach length of 2000 $\mathrm{m}$ was divided into $10 \mathrm{~m}$ intervals. The position of each station was stored in the GPS at MLW (mean low water), and a fishing boat (class G2M, 11 m long with a 22 -HP engine) made $800-\mathrm{m}$ trawls, from the station, 
perpendicular to the beach, from 800 to $1600 \mathrm{~m}$ from MLW. This interval is equivalent to depths from 1 to 4 $\mathrm{m}$. The trawling speed was 1 knot. The trawls were made with two otter trawls with $2.0 \mathrm{~cm}$ mesh, mouth aperture $1.6 \mathrm{~m}$ high and $6.0 \mathrm{~m}$ wide, and bag depth $3.5 \mathrm{~m}$.

The fish were removed from the net and immediately preserved in a $10 \%$ formalin solution in order to paralyze the enzyme action, preserving the digestive-tube contents (UIEDA; CASTRO, 1999). After screening and identification, all C. gracilicirrhus individuals were properly labeled and fixed in $70 \%$ ethanol, and sorted for population, dietary and growth studies.

\section{Data Analysis}

Variation in the species abundance over time (months) and space (South and North areas) was analyzed by two-way ANOVA. A two-way ANOVA was also performed to compare the spatio-temporal variation in total length (TL) of individuals. In all cases, data homogeneity, homoscedasticity, and the robustness of the test allowed the use of ANOVAs, which were followed by Student Newman Keuls (SNK) tests (SOKAL; ROHLF, 1995; UNDERWOOD, 1997).

Growth parameters were estimated based on von Bertalanffy growth curves, by using the FISAT software and following the methodology proposed by Pauly and Garcia (1994). ELEFAN I and Shepherd routines were combined in a general $\mathrm{K}$-scan, in a search for a common peak of optimum goodness-of-fit values for $\mathrm{K}$ (growth constant), before the parameter analysis was further refined. Because the length of the largest individual was below the maximum length reported in previous studies $(21 \mathrm{~cm}$ total length, CERVIGÓN MARCOS, 1993), literature values were used as the basis to define an asymptotic length range for the analysis, dividing by 0.95 as proposed by Taylor (1958) and Beverton (1963).

A total of 160 of the 910 sampled individuals of $C$. gracilicirrhus were selected for dissection, by using a random-digits table. The dissected specimens were used for analyses of sexual maturation, according to Vazzoler (1996), and diet. Because of the large number of fish found in one of the months and relatively few or none in other months, seasonal analyses of diet were not possible. Each digestive tube was removed and its total length measured from the beginning of the esophagus to the end of the rectum (DTTL). Since the stomach is very well-defined and laterally positioned, the total length of the digestive tract essentially corresponds to the length of the intestine. The mean value of the ratio between this value and the fish total length (DTTL/TL) was calculated.
The first part of the digestive tract, including the pharynx, esophagus and stomach were then detached for analysis of food items. The contents of each stomach were identified to the lowest possible taxonomic level, and the volume of each item was measured according to the methodology described by Bemvenute (1990).

For each stomach item, the frequency of occurrence (FO) and percentage volume (V) were calculated. These values were then used to calculate an index of dietary importance (IAi), as proposed by Kawakami and Vazzoler (1980): IAi $=\mathrm{FOi} * \mathrm{Vi} / \Sigma$ (FOi*Vi).

\section{RESULTS}

The density of individuals varied significantly over time $(\mathrm{F}=6.034$, d.f. $=12, \mathrm{p}<0.001)$ and between the two areas $(\mathrm{F}=4.379$, d.f. $=1, \mathrm{p}=0.041)$. The abundance was significantly higher only in May and in the South area, leading to an interaction between factors $(F=5.929$, d.f. $=12, p<0.001)$. This species was one of the most abundant observed during the entire study period (fourth most abundant species, comprising $5.88 \%$ of the total number sampled). However, the mean number of individuals per month and area was larger than 1.0 for only 10 of the 26 cases (Fig. 2). The highest numbers were obtained in November 2003 and April 2004, in the North area (23.67 and 12.33, respectively) and in May 2004, in the South area (236.00).

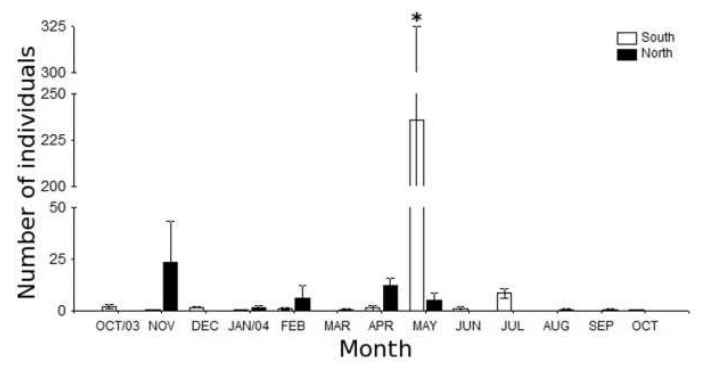

Fig. 2. Spatial and temporal variations in number of individuals (mean \pm standard error; $\alpha=0.05$ ) of Ctenosciaena gracilicirrhus in Caraguatatuba Bay. Individuals were sampled from October 2003 to October 2004. * - significant difference discriminated by SNK test.

Total length of individuals ranged from 4.0 to $10.2 \mathrm{~cm}$; the size ranges by month and area are listed in Table 1. In the North area, the main mode ranged from 6.5 to $7.5 \mathrm{~cm}$. Similar numbers of individuals, with a similar size range, were recorded in the South area. However, here the main mode was from 7.5 to $9.0 \mathrm{~cm}$ (Fig. 3), as a result of the large 
numbers of individuals found in this area and in May 2004, when a high proportion of large individuals were caught.

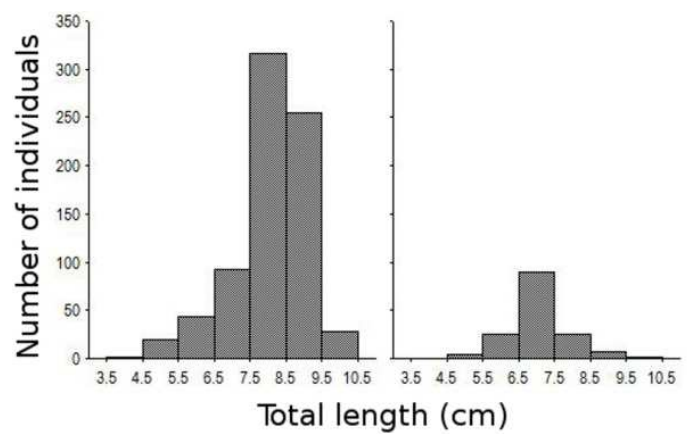

Fig. 3. Distribution of total length $(\mathrm{cm})$ classes of Ctenosciaena gracilicirrhus sampled in Caraguatatuba Bay from October 2003 to October 2004, shown for each sampling area (South and North).

Table 1. Number and ranges of total length (TL, cm) by sampling period and area, of individuals of Ctenosciaena gracilicirrhus (Sciaenidae, Perciformes) collected in Caraguatatuba Bay from October 2003 through October 2004

\begin{tabular}{ccccc}
\hline \multicolumn{5}{c}{ Area/parameter } \\
\hline & \multicolumn{2}{c}{ South } & \multicolumn{2}{l}{ North } \\
\hline Month & $\mathrm{n}$ & TL range & $\mathrm{n}$ & TL range \\
\hline Oct 2003 & 6 & $5.5-7.8$ & 0 & - \\
\hline Nov 2003 & 1 & 7.2 & 71 & $5.1-7.8$ \\
\hline Dec 2003 & 5 & $5.5-8.3$ & 0 & - \\
\hline Jan 2004 & 1 & 7.0 & 4 & $6.0-8.8$ \\
\hline Feb 2004 & 3 & $7.5-7.9$ & 19 & $6.0-7.7$ \\
\hline Mar 2004 & 0 & - & 2 & $6.7-7.8$ \\
\hline Apr 2004 & 4 & $8.7-9.4$ & 37 & $5.8-8.2$ \\
\hline May 2004 & 708 & $5.5-10.2$ & 15 & $7.5-9.9$ \\
\hline Jun 2004 & 3 & $4.0-5.5$ & 0 & - \\
\hline Jul 2004 & 26 & $4.7-7.0$ & 0 & - \\
\hline Aug 2004 & 0 & - & 2 & $5.0-6.5$ \\
\hline Sep 2004 & 0 & - & 2 & $4.7-5.4$ \\
\hline Oct 2004 & 1 & 5.0 & 0 & - \\
\hline & & & & \\
\hline
\end{tabular}

Because the species did not appear in many of the replicate samples, it was not possible to perform a factorial ANOVA. The one-way ANOVA used for comparisons among monthly values indicated significant variations in mean size over time $(\mathrm{F}=57.81$, d.f. $=12, \quad \mathrm{p}<0.001)$, and Student's t-test indicated differences between areas $(t=12.28$, d.f. $=908$, $\mathrm{p}<0.001)$. Mean total length was greater in the South $(8.16 \mathrm{~cm})$ than in the North area $(7.09 \mathrm{~cm})$, and also the size fluctuated more widely in the South. Nevertheless, the pattern of size distribution over time was similar in both areas (Fig. 4). In general, the mean total length remained around 6.5-7.5 $\mathrm{cm}$ from October to March. In April, the mean size increased substantially in the South area, but remained quite constant in the North area. In May, the mean size was the largest, with both areas reaching similar values of mean total length. The lowest mean value was observed in June, with no significant increase until October 2004 (Fig. 4). All dissected individuals $(\mathrm{n}=160$, from 5.4 to $9.9 \mathrm{~cm})$ were immature, and their sex could not be determined.

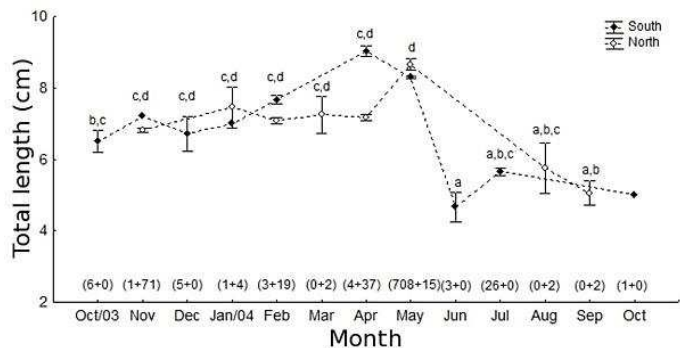

Fig. 4. Spatial and temporal variations of total length $(\mathrm{cm}$; mean \pm standard error; $\alpha=0.05$ ) for Ctenosciaena gracilicirrhus sampled in Caraguatatuba Bay from October 2003 to October 2004. Different letters denote significant differences among months, discriminated by SNK test; brackets on the $\mathrm{x}$-axis enclose the number of observations in each case.

For growth analyses a value of 22.10 was used for asymptotic length (L), which produced a high score $(\mathrm{Rn}=0.409)$ for a growth constant $(\mathrm{K})$ of 0.180 , considering the absence of seasonal fluctuations (C, WP) in growth. However, this result was barely perceptible through manual modal connections, because most individuals were concentrated in a single month. Indeed, Shepherd's method showed a small peak score (around 0.390), agreeing with ELEFAN, but attained the highest score (1.00) for a $\mathrm{K}$ value of 0.320 . Therefore, the analyses were abandoned. Despite the good scores obtained, these results are likely to derive from an artifact related to calculation of the score, rather than to a real characteristic of the population.

Concerning dietary features, the mean DTTL/TL ratio was $0.51 \mathrm{~cm}( \pm 0.14 \mathrm{~cm} \mathrm{SD})$. Of the 160 stomachs analyzed, 52 were empty. For stomachs that did contain food, the content volume ranged from $<1.00$ to $37 \mathrm{~mm}^{3}$.

The identified items consisted of Crustacea, Polychaeta, fish scales, and unidentified eggs. The 
stomach contents were considerably degraded, making it difficult to identify most of the ingested items to a reasonable taxonomic category. Although some individuals were still whole, the tube-constructors such as Amphipoda and Polychaeta were easiest to identify. For these groups, the tubes comprised 80 and $89.7 \%$ of all the organisms identified.

The most important item in both frequency and volume were the Crustacea (Table 2), which had an importance index of over $99.85 \%$. Amphipoda was the only identified subgroup, comprising $7.28 \%$ of the total volume of crustaceans. The other groups had much lower importance indexes, mainly due to their relative volume rather than their frequency, which, however, was also low for all items other than Crustacea.

Nematodes were found in seven of the stomachs, but were considered to be parasites rather than dietary items, because they were much better preserved than the remaining contents.

Table 2. Stomach contents of Ctenosciaena gracilicirrhus (Sciaenidae, Perciformes), collected in Caraguatatuba Bay from October 2003 through October 2004, and the respective values of frequency of occurrence (FO), percentage volume (V) and index of dietary importance (IAi).

\begin{tabular}{lccc}
\hline \hline \multicolumn{1}{c}{ Item } & FO $(\boldsymbol{\%})$ & V (\%) & IAi $(\%)$ \\
\hline Polychaeta & 3.70 & 0.61 & 0.03 \\
\hline Crustacea & 91.67 & 90.01 & 97.90 \\
\hline Amphipoda & 23.15 & 7.06 & 1.94 \\
\hline Fish scales & 5.56 & 1.95 & 0.13 \\
\hline Eggs & 1.85 & 0.37 & 0.01 \\
\hline
\end{tabular}

\section{Discussion}

Ctenosciaena gracilicirrhus showed a peculiar distribution over time in the study area, because, although it is generally among the most abundant species, $82.71 \%$ of all individuals collected occurred in a single month (May 2004) and in the South area. Considering that at least some individuals of $C$. gracilicirrhus were collected in all the months of the study, it can be considered to occur continuously but in relatively low abundance in this bay, even though large numbers may enter the area, where it would then become one of the most abundant fishes. The present observations suggest that some migratory events occur due to the scarce high abundance; the season may differ according to the particularities of the area and the local annual cycle.

A somewhat similar pattern to that observed here was found by Gianinni and Paiva-Filho (1990), who collected only a few $C$. gracilicirrhus in Santos Bay, with considerably higher numbers in autumn. Bernardo et al. (2011), in inshore areas of the state of Paraná, found the highest abundances mainly in January, February and April, this species being much scarcer during the rest of the year.

This characteristic may partially explain why the species is the most (or one of the most) abundant species in some fish community studies conducted on the southeastern and southern inner shelf (ROCHA; ROSSI-WONGTSCHOWSKI, 1998; ROCHA et al., 2010; BERNARDO et al., 2011), whereas in other studies it appears at the bottom of the list or is even absent (ARAÚJO et al., 2002; SCHWARZ Jr., 2006; RODRIGUES et al., 2007). Seasonal samplings of shelf areas would be more likely to result in biased information when extrapolating data for the general composition of the ichthyofauna community, because of the particular features of this population.

The question arises as to whether an occasional diel variation in species abundance might have influenced the observed results for abundance, but the literature indicates that it did not. Rocha et al. (2010) found this species predominantly in daytime, although they observed that other abiotic variables, specifically the site and season, contributed more to the distribution than did the diel variation. This is additional evidence that this factor did not account for the low capture rates in the present study, because our samples were all taken between $09 \mathrm{~h} 00$ and $15 \mathrm{~h} 00$.

It is clear from collection records that $C$. gracilicirrhus shows a preference for outer-shelf areas (GIANINNI; PAIVA-FILHO, 1990; ARAÚJO et al., 2002; SOUZA et al., 2008, ROCHA et al., 2010) and that juveniles are predominant in bays, moving deeper as they grow older (BRAGA; GOITEN, 1984; ROCHA et al., 2010; BERNARDO, 2011). Here, these preferences for outer areas combined with a general and size-associated migratory behavior, could explain: (i) the overall low abundance of individuals; (ii) the occasional higher abundances in one or another area; and (iii) the increase in size from October 2003 to May 2004, after which a significant and constant decrease in size took place. The decrease in the mean size of individuals may reflect the movement of older individuals toward deeper areas and/or the arrival of newer recruits to the area.

Therefore, the high number of individuals observed in May 2004 in Caraguatatuba Bay may have resulted from an influx of individuals, perhaps slightly older residents of deeper areas, because the mean and modal lengths also increased in both areas at that time. Because most of the fish were immature, they probably did not migrate toward shallower areas to reproduce; rather, it is more likely that they had moved opportunistically to feed. This suggestion concords with the larger number of individuals in the 
South area, where the nutrient supply tends to be higher (closer to a larger river). In addition, in that period the riverine influence may have increased because of concurrent rainfall events (consult SINDA, acronym for, in English, the Environmental Data National System; see http://sinda.crn2.inpe.br/PCD/).

These features explain why the good score obtained for the growth analysis (Rn) comes with a caveat, because the data could not support a feasible evaluation of the individual growth parameters. The missing adults, the abundance pattern explained by a migratory behavior, and the subtropical, nearly tropical area, do support arguments such as temporary decreases in individuals' growth rates or fluctuations in growth due to gonad maturation, or a single large recruitment event, which could explain the growthcurve fit. Garcia and Duarte (2006) suggested a growth constant for this species of around 0.24 (without seasonal adjustments) or 0.33 (with adjustments). Their samples, however, in contrast to the present series, lacked younger individuals, because their smallest fish caught was longer than $8.0 \mathrm{~cm}$.

The DTTL/TL ratio less than 1 suggests a fully carnivorous habit (KARACHLE; STERGIOU, 2010), but further assessment of the diet of $C$. gracilicirrhus was impossible because of the highly deteriorated stomach contents, which could not be identified accurately. This seems to be consistent with the biology of the species, for two reasons. First, the identified items are usually bottom-associated groups (Amphipoda, Polychaeta, and fish scales and eggs), in agreement with the species' buccal apparatus including the mouth position and the presence of chin barbels (CUNNINGHAM, 1989). Second, a study comparing the diet of $C$. gracilicirrhus with other sciaenids (MICHELETTI; UIEDA, 1996) also observed a diverse diet. These data also concord with those of the present study, since Polychaeta and Amphipoda were important in the diet of the individuals examined here, which were all less than 10 $\mathrm{cm}$ long. Cunningham (1989) found, between Cabo Frio (state of Rio de Janeiro) and Torres (state of Rio Grande do Sul), Amphipoda (Gammaridae) and Polychaeta as the main food items of $C$. gracilicirrhus, along with other benthic crustaceans (Penaeidae, Tanaidacea, Cumacea, etc.), eggs, diatoms, foraminifera and Bivalvia. The strong benthic-feeding habit of this species possibly leads to the ingestion of large amounts of items that have settled to the bottom, which would already be decomposing. Therefore, whether due to a scavenger habit or to accidental ingestion, C. gracilicirrhus seems to be prone to ingest large amounts of degraded items.

\section{ACKNOWLEDGEMENTS}

This study was partly financed by the State of São Paulo Research Foundation (FAPESP) within the Biota/FAPESP - The Biodiversity Virtual Institute Program (www.biota.org.br). We also thank FAPESP for the "Programa Jovem Pesquisador em Centro Emergente" grant offered to M. R. D. (Proc. No. 05/60041-6 and 06/57575-1). The Project Aware Foundation and the Padi Foundation also financed part of this research project. Essential logistical support was provided by the Instituto Costa Brasilis Desenvolvimento Sócio-Ambiental and the University Center of the Fundação de Ensino Octávio Bastos. We are grateful to A. P. Majer, G. M. Dias, and C. G. M. Delboni for their assistance in the fieldwork.

\section{REFERENCES}

ARAÚJO, F. G.; AZEVEDO, M. C. C.; SILVA, M. A.; PESSANHA, A. L. M.; GOMES, I. D.; CRUZ FILHO, A. G. Environmental influences on the demersal fish assemblages in the Sepetiba Bay, Brazil. Estuaries, v. 25, n. 3, p. 441-450, 2002.

ARAÚJO, F. G.; GUIMARÃES, F. C.; COSTA, M. R. Environmental influences on distribution of four Sciaenidae species (Actinopterygii, Perciformes) in a tropical bay at Southeastern Brazil. Rev. Bras. Zool., v. 23, n. 2, p. 497-508, 2006.

BEMVENUTE, M. A. Hábitos alimentares de peixes-rei (Atherinidae) na região estuarina da Lagoa dos Patos. Atlantica, v. 12, n. 1, p. 79-102, 1990.

BERNARDO, C.; SPACH, H. L.; SCHWARZ Jr., R.; STOIEV, S. B.; CATTANI, A. P. The by-catch of Sciaenidae fishes in experimental fishing with an otter trawlnet used in the seabob shrimp, Xiphopenaeus kroyeri, fishery in Paraná State, Brazil. Arq. Cienc. Mar, v. 44, n. 2, p. 98-105, 2011.

BEVERTON, R. J. H. Maturation, growth and mortality of Clupeid and Engraulid stocks in relation to fishing. Rapp. CIEM, v. 154, p. 44-67, 1963.

BRAGA, F. M. S.; GOITEIN, R. Lista prévia das espécie de peixes demersais na região da ilha Anchieta (Lat.23 $33^{\circ} \mathrm{S}$ - Long. $45^{\circ} 05^{\prime} \mathrm{W}$ ), Ubatuba, litoral norte do Estado de São Paulo, Brasil. Naturália, v. 9, p. 6172, 1984.

CERVIGÓN MARCOS, F. Los peces marinos de Venezuela. Caracas: Fundación Científica Los Roques, 1993. v. 2.

CHAO, L. N. Sciaenidae. In: FISCHER, W. (Ed.) FAO species identification sheets for fishery purposes: West Atlantic (Fishing Area 31). Rome: FAO, 1978. p. irreg.

CUNNINGHAM, P. T. M. Observações sobre o espectro alimentar de Ctenosciaena gracilicirrhus (Metzelaar), Sciaenidae. Rev. Bras. Biol., v. 49, n. 2, p. 335-339, 1989. 
GARCIA, C. B.; DUARTE, L. O. Length-based estimates of growth parameters and mortality rates of fish populations of the Caribbean Sea. J. Appl. Ichthyol., v. 22, n. 3, p. 193-200, 2006.

GIANINNI, R.; PAIVA-FILHO, A. M. Os Sciaenidae (Teleostei, Perciformes) da Baía de Santos (SP), Brasil. Bol. Inst. Oceanogr., v. 38, n. 1, p. 69-86, 1990.

GILLANDERS, B. M.; ABLE, K. W.; BROWN, J. A.; EGGLESTON, D. B.; SHERIDAN, P. F. Evidence of connectivity between juvenile and adult habitats for mobile marine fauna: an important component of nurseries. Mar. Ecol.: Prog. Ser., v. 247, p. 281-295. 2003.

KARACHLE， P. K.; STERGIOU, K. I. Intestine morphometrics of fishes: a compilation and analysis of bibliographic data. Acta Ichthyol. Piscatoria, v. 40, p. 45-54, 2010.

KAWAKAMI, E.; VAZZOLER, G. Método gráfico e estimativa de índice alimentar aplicado no estudo de alimentação de peixes. Bol. Inst. Oceanogr., v. 29, n. 2 p. 205-207, 1980 .

MENEZES, N. Relação dos peixes ósseos coletados durante os cruzeiros do navio oceanográfico "Prof. W. Besnard" às costas do Rio Grande do Sul. Contribuições Avulsas Inst. Ocean. Univ. São Paulo, Ser. Oceanogr. Biol., v. 25, p. 44-61, 1971.

MICHELETTI, C. V.; UIEDA, V. S. Food resources partitioning among Sciaenid fishes (Perciformes, Sciaenidae) of the Flamengo Bay, Ubatuba, Southeastern Brazil. Arq. Biol. Tecnol., v. 39, n. 3, p. 639-649, 1996

PAULY, D.; GARCIA, S. Announcing the release of FiSAT (Version 1.0). Naga, ICLARM Q., v. 17, n. 4, p. 46-47, 1994.

ROCHA, G. R. A.; ROSSI-WONGTSCHOWSKI, C. L. D. B. Demersal fish community on the inner shelf of Ubatuba, southeastern Brazil. Rev. Bras. Oceanogr., v. 46, n. 2, p. 93-109, 1998.

ROCHA, M. L. C. F.; FERNANDEZ, W. S.; PAIVAFILHO, A. M. Spatial and temporal distribution of fish in Palmas bay, Ubatuba, Brazil. Braz. J. Oceanogr., v. 58, n. 1, p. 31-43, 2010.

RODRIGUES, C.; LAVRADO, H. P.; FALCÃO, A. P. C.; SILVA, S. H. G. Distribution of the ichthyofauna captured by otter-trawl in Guanabara Bay, Rio de Janeiro, Brazil. Arq. Mus. Nac. (Rio de Janeiro), v. 65, n. 2, p. 199-210, 2007.
SÃO PAULO (Estado). Secretaria do Meio Ambiente. Coordenadoria de Planejamento Ambiental, Estratégico e Educação Ambiental. Litoral Norte. São Paulo: SMA/CEPLEA. 2005. 112p.

SASAKI, K. 1989. Phylogeny of the family Sciaenidae, with notes on its zoogeography (Teleostei, Perciformes). Memoirs of the Faculty of Fisheries, Hokkaido University, 36(1-2): 1-137. 1989.

SCHWARZ Jr., R.; FRANCO, A. C. N. P.; SPACH, H. L.; SARPEDONTI, V.; PICHLER, H. A.; NOGUEIRA DE QUEIROZ, G. M. L. Composition and structure of the demersal ichthyofauna in the Pinheiros Bay, Paraná, Brazil. Braz. J. Aquat. Sci. Technol., v. 10, n. 1, p. 2739, 2006.

SOKAL, R. R.; ROHLF, F. J. Biometry: the principles and practice of statistics in biological research. New York: W. H. Freeman, 1997. 887 p.

SOUZA, U. P.; COSTA, R. C.; MARTINS, I. A.; FRANSOZO, A. Associações entre as biomassas de peixes Sciaenidae (Teleostei: Perciformes) e de camarões Penaeoidea (Decapoda: Dendrobranchiata) no litoral norte do Estado de São Paulo. Biota Neotrop., v. 8, n. 1, p. 83-92, 2008.

TAYLOR, C. C. Cod growth and temperature. ICES J. Mar. Sci., v. 23, n. 3, p. 366-370, 1958.

UIEDA, V. S.; CASTRO, R. M. C. Coleta e fixação de peixes de riachos. In: CARAMASCHI, E. P.; MAZZONI, R.; PERES, P. R. (Ed.). Ecologia de peixes de riachos. Rio de Janeiro: PPGE-UFRJ, 1999. p. 1-22. (Série Oecologia Brasiliensis).

UNDERWOOD, A. J. Experiments in ecology: their logical design and interpretation using analysis of variance. Cambridge: Cambridge University Press, 1997. 504 p.

VAZZOLER, A. E. A. M. Biologia da reprodução de peixes Teleósteos: teoria e prática. Maringá. Maringá: Eduem, 1996. 169 p.

(Manuscript received 10 April 2013; revised 17 September 2013; accepted 18 September 2013) 